
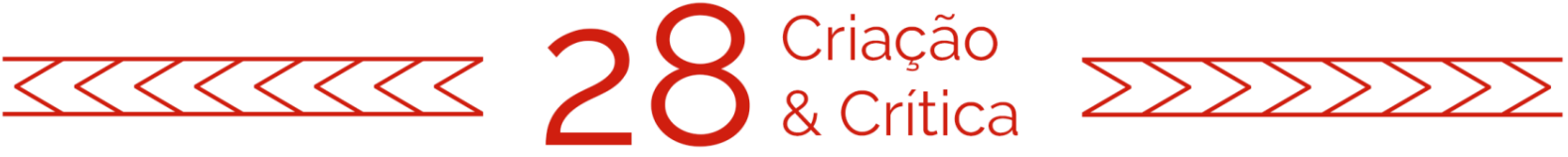

\title{
DRUMMOND E A ASSOCIAÇÃO BRASILEIRA DE ESCRITORES: DESENCONTROS E RUPTURA
}

Marcelo Bortoloti ${ }^{1}$

Resumo: Nos anos 1930 e 1940, o poeta Carlos Drummond de Andrade viveu sua fase de maior engajamento político, aproximando-se do Partido Comunista e incorporando à sua poesia, antes intimista, temas coletivos e sociais. A partir de 1947, no entanto, esta postura começa a esmorecer, levando o escritor a uma isenção ideológica ou, antes disso, a uma clara aversão a seus antigos companheiros de jornada. Este artigo esmiúça o ponto mais tumultuado deste conflito, que foi a atuação de Drummond junto à Associação Brasileira de Escritores, expondo as oscilações do poeta na sua ação política e, simultaneamente, também em sua obra. A trajetória do autor testemunha os limites da comunhão de escritores em torno de causas coletivas, sobretudo nos períodos de maior tensão político-ideológica.

PALAVRAS-ChAVE: Carlos Drummond de Andrade; Associação Brasileira de Escritores; Comunismo no Brasil; Guerra Fria; Realismo Socialista.

\section{DRUMMOND AND THE BRAZILIAN WRITERS 'ASSOCIATION: DISCONTINUES AND BREACH}

ABSTRACT: In the 1930s and 1940s, the poet Carlos Drummond de Andrade lived his phase of greater political engagement, approaching the Communist Party and incorporating collective and social themes into his poetry, previously intimate. From 1947, however, this attitude began to fade, leading the writer to an ideological exemption or, before that, to a clear aversion to his former journey companions. This article breaks down the most tumultuous point of this conflict, which was Drummond's work with the Brazilian Writers Association, exposing the poet's oscillations in his political action and, simultaneously, also in his work. The poet's trajectory testifies to the limits of the writers' communion around collective causes, especially in periods of greater politicalideological tension.

KEYwords: Carlos Drummond de Andrade; Brazilian Writers Association; Communism in Brazil; Cold War; Socialist realism.

Na Europa dos anos 1930, um intenso conflito político-ideológico ganhava terreno enquanto uma nova guerra mundial começava a despontar no horizonte. $O$ nazismo e o fascismo fortaleciam-se na Alemanha e na Itália, ao mesmo tempo em que a União Soviética irradiava um modelo de organização social e política que ia na vertente oposta. Intelectuais de todo o Ocidente foram tocados por esta disputa, numa luta que seria, na maioria dos casos, contra o fascismo, mas também em nome de uma sociedade mais

1 Doutor em Literatura Brasileira pela Universidade Federal do Rio de Janeiro (marcelobortoloti@gmail.com). 

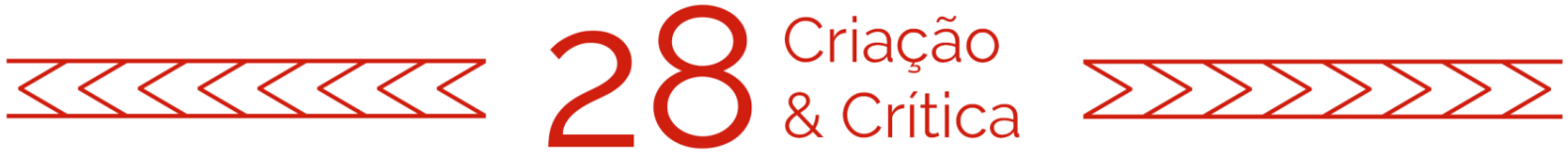

justa. O socialismo era então encarado como um modelo com chances reais de quebrar a hegemonia do sistema capitalista, fragilizado com a crise de 1929, da qual a União Soviética saíra praticamente ilesa.

Assim como tantos outros escritores, o poeta Carlos Drummond de Andrade (1902-1987), começou a ser tocado por este embate em meados de 1935, incorporando temas sociais à sua poesia, até então voltada estritamente a assuntos intimistas. A partir de um sentimento antifascista, e da consciência do papel que cabia a todo escritor naquele momento histórico, aderiu às ideias socialistas e aproximou-se do comunismo. Em pouco mais de uma década, portou-se como um "companheiro de viagem", termo cunhado por Leon Trotsky para classificar os artistas e intelectuais simpatizantes da Revolução de 1917. Foi com este espírito que atravessou eventos emblemáticos como a Guerra Civil Espanhola (1936-1939) e a Segunda Guerra Mundial (1939-1945). Em 1945, abraçou a causa com maior sectarismo: visitou o líder Luís Carlos Prestes na cadeia para pedir instruções, trabalhou na diretoria do jornal oficial do Partido Comunista, a Tribuna Popular, e por pouco não se lançou como candidato a deputado pela legenda. Ao longo de todo este período, escreveu quatro obras embebidas do espírito revolucionário da época - Sentimento do mundo (1940), José (1942), A rosa do povo (1945) e Novos poemas (1947), este último já num momento de transição, portanto, trazendo apenas os resquícios da fase engajada.

O sonho de um mundo mais justo, onde os homens marchariam de mãos dadas, no entanto, durou pouco - o relacionamento de Drummond com os comunistas acabou de forma conturbada. Em 1949, o poeta trocava empurrões com militantes do Partido Comunista, que queriam arrancar da sua mão o livro de atas de uma reunião da Associação Brasileira de Escritores. Foi tratado como traidor pelos periódicos de esquerda e, por sua vez, alfinetou os adversários em colunas de jornal. Este momento de ruptura, objeto do presente artigo, testemunha os limites de cooperação e comunhão entre escritores que ficariam evidentes naquele momento de grande tensão político-ideológica.

O cenário externo em que ocorreu foi marcado pela Guerra Fria, que impulsionava o sectarismo ideológico global. Na disputa pela expansão de sua influência política e econômica, as duas grandes potências mundiais que saíram fortalecidas da Segunda Guerra, Estados Unidos e União Soviética, intensificaram o conflito de ideias que teve eco em países como o Brasil. No campo da literatura comunista, o embate resultou em um novo hasteamento da bandeira do realismo socialista, corrente que, grosso modo, admitia uma produção literária simplificada, de conteúdo direto e interessado. Ainda que combatida por parte da militância de esquerda e dos "companheiros de viagem", esta era a premissa ditada por Moscou desde 1934. Depois de 1946, com o sopro do sectarismo soviético difundido entre intelectuais do Ocidente, tal corrente literária ficou mais em evidência. (BOWRA, 1969, p. 152).

Andrei Zhdanov, grande propagandista deste modelo de escrita, foi tema constante nas rodas literárias com sua defesa do papel do escritor como elemento útil ao governo na formação intelectual do povo. Para ele, a tarefa da literatura consistia em "ajudar o Estado a educar a juventude apropriadamente, a satisfazer seus requisitos, a 

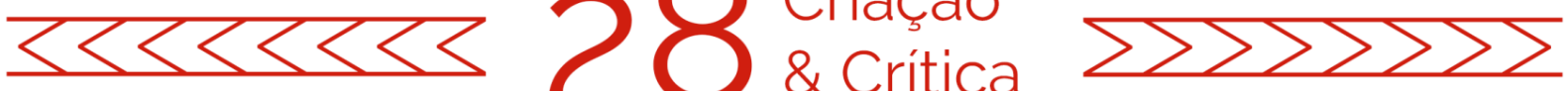

preparar a nova geração para que seja forte, tenha fé na sua causa, não tema os obstáculos e esteja disposta a vencer todas as dificuldades". (apud BOWRA, 1969, p. 152). Essa diretriz teve profundo impacto na poesia soviética e por consequência na literatura mundial. Maurice Bowra, no livro Poesia y politica, afirma que, de 1946 até 1953, a poesia russa passou por seu período mais estéril, e muito pouco do que se publicou poderia ter relevante valor literário. $O$ autor continua:

Se um país como a Rússia, onde triunfou a revolução, cometeu estes tremendos erros, não era provável que outros países, onde os velhos sistemas de governo seguiam prevalecendo, produzissem poetas que pudessem tratar de temas revolucionários sem algum sacrifício de sua arte. Rússia servia muito como modelo para que seguissem seu próprio caminho, e as teorias russas sobre a utilidade dos escritores para o Estado e a sociedade provocaram em muitos poetas europeus um conflito interior que afetou profundamente a sua obra. (BOWRA, 1969, p. 156).

Neste contexto, os "companheiros de viagem" foram forçados a tomar uma posição. Ou estavam a favor da causa comunista, e neste caso deveriam seguir a orientação e a disciplina do partido, ou estavam contra ela. Foi um momento em que vários escritores, inclusive Drummond, afastaram-se da luta. ${ }^{2}$ Por outro lado, foi também um tempo em que alguns abraçaram-na com vigor, passando a produzir uma literatura cada vez mais sectária, como Jorge Amado em seu livro O mundo da paz (1951).

O quadro político no Brasil favorecia o embate ideológico que ganhava escala em nível global. O presidente que substituiu o ditador Getúlio Vargas, há 15 anos no poder, Eurico Gaspar Dutra, levou adiante um governo marcado pelo combate aos comunistas e alinhamento às forças americanas. Em dezembro de 1946, um fato mais anedótico do que grave serviu de justificativa para o rompimento das relações diplomáticas entre Brasil e União Soviética. O secretário da embaixada brasileira em Moscou, João Batista Soares de Pina (conhecido como "Pina Gomalina", pelo hábito de fixar os cabelos com o produto), aparentemente bêbado, promoveu um quebra-quebra num hotel de luxo da capital soviética. Ele foi preso e a conta enviada ao Brasil, cujo governo precisava apenas de um pretexto para romper relações com os soviéticos. Pela repercussão negativa do episódio na imprensa brasileira, ficava nítido o sentimento anticomunista que já ganhava a opinião pública.

Em maio de 1947, teve início a cassação do registro do Partido Comunista pelo Supremo Tribunal Federal. O PCB era o quarto principal partido do país, com cerca de 200 mil militantes, e no pleito de 1945 havia eleito dezenas de deputados e senadores. Todos perderiam o mandato. O partido foi caçado por estar supostamente obedecendo orientações da União Soviética em território nacional. Era uma denúncia controversa, feita por parlamentares obscuros como Barreto Pinto, que se notabilizaria pouco tempo depois

\footnotetext{
${ }^{2}$ Disse o poeta em entrevista a Edmilson Caminha, em 1984: "Nunca fiz parte do Partido Comunista, mas fui um namorado muito próximo dele. Eu cumpri tarefas que os comunistas cumprem. Apenas não me engajei porque, conhecendo o meu individualismo talvez um pouco exacerbado, achei melhor dar minha adesão aos ideais comunistas na prática, sem me comprometer entrando para os quadros partidários. A disciplina era muito férrea, e eu não teria condições de obedecer a ela". (CAMINHA, 2002).
} 

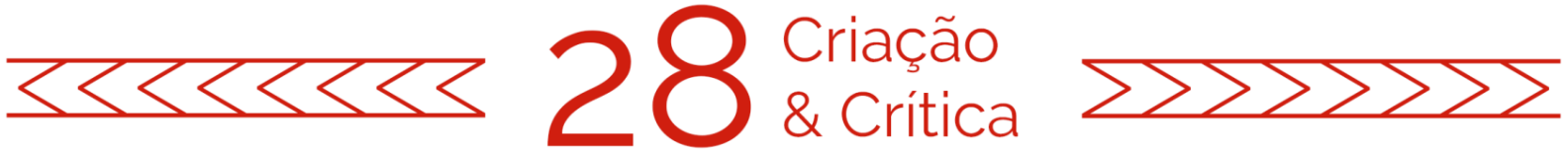

por aparecer de cuecas numa revista de circulação nacional, episódio que o fez perder o mandato. Mas a denúncia serviu de justificativa plausível naquele momento de embate ideológico global. Até o final do governo Dutra, 200 sindicatos ou entidades de classe sofreram intervenção federal acusados de estarem sob influência dos comunistas.

Para Drummond, o período que vai do final da Segunda Guerra até o início da década de 1950 foi um momento de virada, no qual ele tornou-se um fervoroso adversário dos antigos aliados. Simultaneamente, sua poesia desincorporou os problemas do tempo presente e a causa revolucionária para voltar-se a temas intimistas e mais metafísicos, expressos no livro Claro Enigma. Sua posição anticomunista começou na Associação Brasileira de Escritores e culminou na adesão à campanha presidencial do sucessor escolhido por Dutra, Cristiano Machado.

Esta ruptura teve início durante a tentativa de controle da Associação Brasileira de Escritores por parte dos comunistas. Àquela altura, com o partido na ilegalidade, seus antigos integrantes procuravam se infiltrar em associações civis de naturezas diversas para poder agir politicamente. A ABDE foi criada no Rio de Janeiro em fevereiro de 1943, com objetivo de defender o interesse dos escritores. Drummond fez parte da primeira diretoria, como vice-presidente, e foi responsável pela redação do primeiro estatuto da associação. A missão inicial da entidade era a fiscalização e a cobrança de direitos autorais, no Brasil e no exterior, bem como zelar pela assistência a seus sócios e a outros escritores necessitados de maneira geral. Assim como as entidades internacionais que surgiram na Europa nos anos 1930, a ABDE não pôde se esquivar de seu caráter político numa época em que os escritores eram chamados a tomar parte na luta antifascista.

Em 1945, foi organizado o primeiro congresso da associação, em São Paulo, onde se reuniram 500 escritores para discutir os problemas da categoria, e o debate resultou numa declaração de princípios que condenava a censura e o governo ditatorial no Brasil. Já nesta época, parte dos escritores reprovava a presença dos comunistas na associação e o viés político que estava tomando a entidade que, a princípio, deveria zelar exclusivamente pelo interesse dos seus integrantes. Drummond não participou do primeiro congresso, já que ainda estava vinculado ao governo Vargas, como chefe de gabinete no Ministério da Educação e Saúde, mas enviou um telegrama de solidariedade ao protesto contra a ditadura. Esta declaração conjunta dos intelectuais teve uma repercussão importante na imprensa e ajudou no enfraquecimento do regime.

O segundo congresso dos escritores ocorreu em Belo Horizonte no ano de 1947, quando a ditadura já havia caído, e o Brasil entrara num período supostamente democrático, no qual, entretanto, o Partido Comunista teve o seu registro cassado pelos motivos acima expostos. Os associados continuavam divididos entre aqueles que defendiam a participação política da entidade e os que advogavam manter seu foco em questões específicas da categoria. Segundo estes, qualquer envolvimento político poderia prejudicar o objetivo final da instituição, que era o de zelar pelos direitos autorais de todos os escritores, independentemente de suas convicções ideológicas. Neste momento, começava a ficar clara a diferença de posições entre Drummond e o Partido Comunista. 

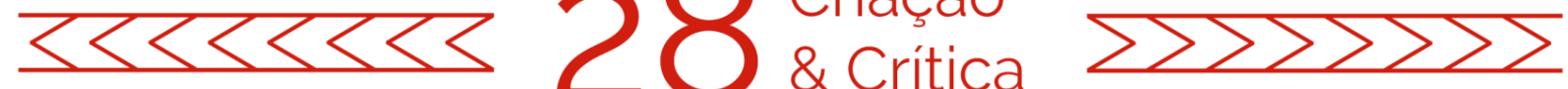

Durante o congresso, o escritor Aires da Mata Machado Filho propôs uma moção para que a ABDE se pronunciasse contra a Lei de Segurança do governo Dutra, o fechamento do Partido Comunista e a tentativa de cassação dos mandatos dos deputados da legenda. Drummond fazia parte da Comissão de Assuntos Políticos da entidade e ameaçou renunciar caso a moção fosse acatada. Junto com outros escritores, ele conseguiu 70 assinaturas para invalidar o pedido de Mata Machado, sob alegação de que a associação deveria manter-se neutra no episódio. Segundo o jornal Diário Trabalhista, a tentativa de politização do congresso foi barrada pela resistência de alguns escritores, "entre os quais tomou posição de combate Carlos Drummond de Andrade que, ao contrário do que alguns poderiam pensar, nem é comunista nem é burro". (UM GOLPE...,1947, p. 1).

A declaração final do congresso teve certo viés político interpretado por alguns escritores como uma vitória dos comunistas. Dizia o primeiro tópico da declaração que seria desejável à atividade literária não se restringir ao domínio estético: "O escritor pode se conservar dentro desse domínio", observava o texto, "mas é certo que poderá também vir a engrandecer a missão da inteligência fazendo de sua obra um instrumento de participação consciente na exposição e solução dos problemas da coletividade". (ENCERROU-SE O CONGRESSO...,1947). Apesar desta vitória parcial, militantes do partido começaram a atacar Drummond através da imprensa, pela obstrução que ele havia impingido ao protesto contra a cassação da legenda. No jornal Correio da Manhã, o poeta comentou os ataques:

Desgostoso com a minha atitude na ABDE, no sentido de impedir, com outros escritores, que nossa entidade profissional degenerasse em instrumento de política partidária - o que conseguimos - o Partido Comunista escalou o sr. Moacyr Werneck de Castro para atacar-me. Sou grato pela escolha, que recaiu num moço inteligente, afeiçoado às letras, e capaz de renovar em parte os clichés com que o Partido pretende fulminar indiscriminadamente quantos incorram no seu desagrado. (ANDRADE, 1947, p. 1)

Dois anos depois, em 1949, um conflito mais sério ganhou corpo por motivo semelhante. O terceiro Congresso Brasileiro de Escritores estava programado para acontecer em Salvador. Antes disso houve uma eleição para a diretoria da entidade no Rio de Janeiro, onde funcionava a representação nacional da ABDE. Para os comunistas, assumir a diretoria da entidade seria uma vitória importante, pois facilitaria a condução do congresso para assuntos de ordem política, respondendo à situação de repressão que o país vivia.

As duas chapas inscritas representavam uma divisão clara entre os escritores pertencentes à associação. De um lado os comunistas, representados por uma chapa que tinha Homero Pires na presidência, escritor não ligado ao partido que emprestava um caráter de neutralidade ao grupo, e Orígenes Lessa como vice. O conselho diretor era formado por Aníbal Machado, Astrojildo Pereira e Graciliano Ramos. Eles se propunham a 

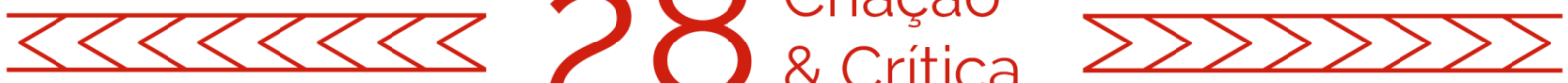

defender os interesses da categoria, mas também a participar da luta política do país. Um panfleto da chapa falava da missão da nova diretoria:

Condenar sempre, em termos claros e enérgicos, as leis de 'repressão' às ideias e às manifestações de pensamento, a incitação à guerra, o ódio à cultura que se manifesta através da propaganda guerreira, de perseguição aos escritores, empastelamento e fechamento de jornais e revistas, interdição e invasão de clubes culturais, censura à obra literária e teatral e à simples canção popular. (PELA VITÓRIA..., S/D)

A chapa opositora tinha Afonso Arinos de Melo Franco na presidência, sendo Drummond o primeiro secretário. No conselho fiscal estava o líder religioso Alceu Amoroso Lima, inimigo declarado dos comunistas. O grupo era apoiado por escritores que iam de orientação política de centro até extrema direita. E sua proposta era transformar a ABDE em uma entidade politicamente neutra focada na defesa dos direitos dos escritores. No fundo, a intenção era extirpar a influência comunista na associação.

Um artigo em defesa da chapa, publicado na imprensa da época, comentava a "deformação" a que a ABDE passara nos últimos anos, argumentando que há tempos essa "facção política" influía na vida do órgão de classe, em cujo quadro social conseguira "infiltrar centenas de seus militantes, desconhecidos como escritores, mas atentos às palavras de ordem do partido e dispostos a toda sorte de práticas de emergência".(FIM DA ABDE..., 1949). De acordo com o artigo, os comunistas conseguiram influir no regulamento da entidade, de forma que um indivíduo que tivesse publicado dois ou três artigos em jornal já poderia ser afiliado e ter direito a voto. O quadro de associados de fato era heterogêneo, e tinha entre eles até o "escritor" Luís Carlos Prestes.

Neste pleito, a associação tornou-se um microcosmo da disputa ideológica que se travava em escala global. Era uma reprodução da mesma disputa que se dera nos anos 1930, que fomentara a Guerra Civil Espanhola e posteriormente a Segunda Guerra Mundial. Dessa vez, com os regimes fascistas fora do jogo, o embate era entre as forças do capitalismo e do comunismo global. Um editorial do jornal $O$ Globo relacionava essa luta política internacional com as eleições da ABDE:

Trava-se novamente nos principais centros culturais do mundo, como antes da hecatombe provocada pelo nazismo, uma intensa guerra intelectual entre duas concepções de vida. Desta vez, afastado o materialismo de Hitler, defrontam os espíritos liberais e democráticos - ou seja, todos aqueles que colocam acima de tudo a liberdade e a dignidade do homem - a exacerbação do materialismo marxista. E seria inevitável que no Brasil de ontem como de hoje repercutissem os ecos dessa luta, cujos agentes sempre preferem as instituições culturais para teatro subterrâneo ou ostensivo de todas as intrigas e dissídios. (PROFISSIONAL E NÃO...., 1949, p.1).

O nome de Afonso Arinos não era bem visto pelos comunistas. Como deputado, ele era um dos líderes da UDN, partido que dava apoio ao governo de Dutra. Segundo 

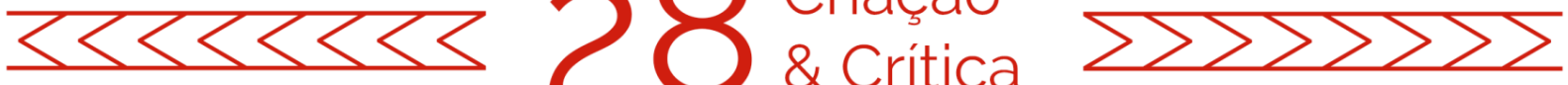

Moacyr Werneck de Castro, a atuação de Arinos como parlamentar caracterizava-se "pela preocupação de arranjar forma legal para diversos instrumentos de opressão forjados pelo governo. Deem-Ihe uma lei franquista, ele a transforma em estatuto 'constitucional'". (CARTA A UM..., S/D). Para Castro, essa atividade não se conciliava com as obrigações de defender a liberdade e a paz, assumidas pelos escritores nos dois congressos realizados em São Paulo e Belo Horizonte. "Elegê-lo será prestar um serviço aos que sonham transformar a ABDE num clube inócuo, inodoro e inoperante", argumentava o texto, "onde os escritores esqueçam os deveres formulados na sua primeira Declaração de Princípios ou pior ainda, [transformá-lo] num centro de reação".

Ainda assim, Arinos obteve uma vitória com diferença de cem votos. Sua chapa recebeu 478 votos, contra 378 obtidos pelo grupo liderado por Homero Pires e ligado aos comunistas. Drummond foi chamado de "arquiteto da vitória", pois esteve à frente de toda a articulação política da chapa vencedora. Os jornais da época informavam sobre o trabalho do poeta nos bastidores. Ao declarar seu voto em artigo do Correio da Manhã, Álvaro Lins escreveu: "Darei meu voto a todos os candidatos da chapa encabeçada por Afonso Arinos, e na liderança da qual vejo o meu caro amigo Carlos Drummond de Andrade". (LINS, 1949, p. 1). Segundo Danton Jobim, "as glórias da jornada couberam inegavelmente ao grande Carlos Drummond de Andrade, que soube empunhar com bravura a bandeira da libertação da ABDE”. (JOBIM, 1949)

Carlos Lacerda, em artigo também no Correio da Manhã, afirmava que seria importante destacar o "valor e a significação" do esforço de Carlos Drummond de Andrade, a quem se devia a decisão de resistir à dominação comunista na ABDE: "Ele viu de perto. Ele sentiu. Ele sabe. Precisamente porque o seu nome foi emprestado para figurar no cabeçalho da antiga Tribuna Popular, os comunistas não se atrevem a atacá-lo de frente". (LACERDA, 1949, p.2). Por outro lado, Drummond foi perseguido por jornais comunistas como a Folha do Povo, que em março publicou nota com o seguinte teor:

Entre outras coisas, o senhor Carlos Drummond de Andrade tem fama de homem calado. Mas outro dia foi visto fazendo um pequeno comício nas proximidades da Biblioteca Nacional, numa roda de amigos, contra o comunismo e em nome dessa chapa do senhor Afonso Arinos de Melo Franco, cuja candidatura à presidência da ABDE por sina, é também apoiada pelos jovens integralistas do suplemento de $A$ Manhã. Vê-se assim que o s.r. Carlos Drummond é um homem calado apenas quando o silêncio Ihe interessa. (SQUEFF, 1949)

A chapa comunista não aceitou o resultado das eleições e queria a impugnação do pleito. O pretexto alegado é que a maioria dos votos obtidos pelo grupo vitorioso foi dada por procuração, e não por escritores que votaram pessoalmente. Sem as procurações, a chapa de Afonso Arinos teria apenas 116 votos. Um artigo na Folha do Povo dizia que a exigência dos comunistas era que tais procurações, "pescadas à tarrafa" por Rubem Braga, Carlos Drummond e Ivete Vargas "nas repartições públicas, nos gabinetes dos bancos, nos asilos da velhice desamparada e nos círculos do acordo interpartidário, sejam devidamente discutidas em assembleia”. (OS QUIXOTES..., 1949). 

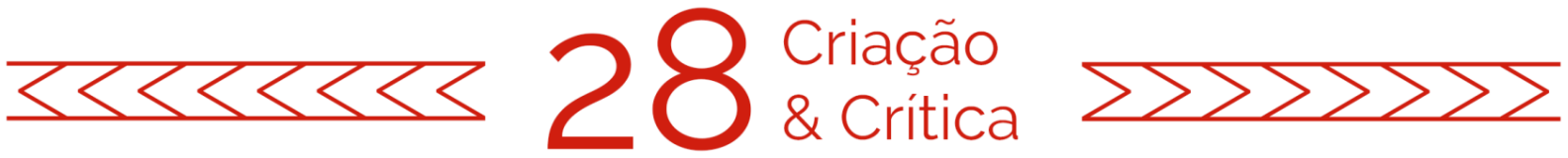

O argumento era frágil porque os votos de escritores ausentes foram contabilizados em eleições anteriores.

O pleito ocorreu no final de março e a chapa de Afonso Arinos, oficialmente eleita, tomaria posse no dia 7 de abril. Mas um novo confronto ocorreria durante a cerimônia, agravando a crise entre Drummond e os comunistas, implodindo a associação, a qual seria esvaziada num ato de protesto alguns dias depois. A posse ocorreu na Casa do Estudante do Brasil, no centro do Rio, ocasião em que militantes comunistas compareceram em massa, segundo seus adversários, para tumultuar a sessão. A diretoria anterior passou oficialmente o mandato ao grupo eleito, entregando os documentos e livros de gestão nas mãos de Drummond, primeiro secretário. Entre estes estava o livro de atas com o registro da transmissão de cargo. Neste momento, o escritor Dalcídio Jurandir, à frente de um grupo de militantes, arrancou o livro das mãos do poeta e o atirou ao chão, dando início a um tumulto que acabou em enfrentamento corporal. Os jornais da época descrevem o episódio. Lê-se, por exemplo, no jornal O Mundo:

Contra o nosso maior poeta, investiram os leiteiros e motoristas do PCB, querendo arrebatar-Ihe os livros da secretaria. E como ele resistisse com uma bravura e uma força surpreendentes, no seu físico de asceta, os pichadores de paredes, instigados pelo senhor Dalcídio Jurandir e com a aprovação de Pedro Mota Lima, agrediram-no covardemente, sendo contidos pelos escritores presentes. Drummond revidou o assalto com uma bravura enorme. Parecia uma onça pintada. (ESCREVEM A PIXE..., 1949, p.1).

O jornal Diário da Noite deu destaque à manchete: "Agredido pelos comunistas o escritor Carlos Drummond de Andrade”. (AGREDIDO..., 1949, p.2). No Diário Carioca, outra descrição pormenorizada do caso:

Dalcídio Jurandir, entre vociferações, arrebatou o livro de atas da Associação, no qual, entre outras, se encontrava a ata da assembleia geral da eleição, atirando-o ao chão. O poeta Carlos Drummond de Andrade, na qualidade de primeiro secretário da nova diretoria, atirou-se em defesa do livro, arrebatando-o das mãos da brigada de choque de escritores desconhecidos comunistas. Apoderou-se do mesmo em meio a uma troca de sopapos e pontapés, defendendo-se energicamente. (GOLPE DOS..., 1949, p. 1).

De acordo com o noticiário, depois do incidente, a chapa eleita estudava algumas medidas a tomar em retaliação ao tumulto causado pelos comunistas. Uma delas seria expulsar os associados responsáveis pela baderna. A outra seria uma renúncia da diretoria empossada e a retirada em massa da associação, com objetivo de criar uma nova entidade, sem a infiltração dos comunistas. Drummond trabalhou pela segunda alternativa. Três dias depois do ocorrido, escreveu ao amigo Abgar Renault:

Preciso de você uma declaração assim: "Tendo tomado conhecimento da resolução da diretoria e conselho fiscal da Associação Brasileira de 

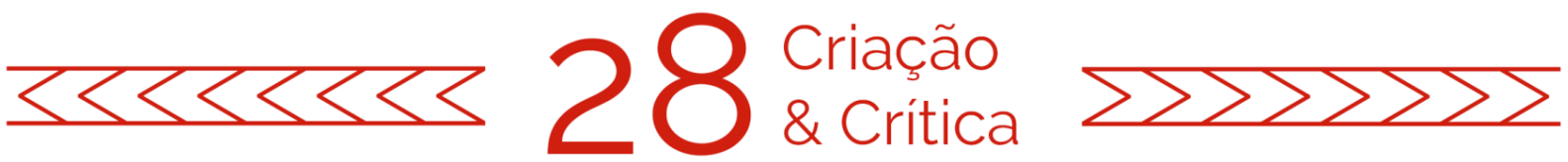

Escritores, seção do Distrito Federal, sob a presidência do consórcio Afonso Arinos de Melo Franco, de renunciar e afastar-se da entidade, venho nesta data igualmente desligar-me da referida seção. B.H., etc.". Todos os nossos amigos estão firmando declaração idêntica. (ANDRADE, 1949a).

A correspondência do poeta guarda registro de outros pedidos com o mesmo teor, inclusive para escritores menos próximos, como Luís Cosme, para quem escreveu no final deste mês:

Disse-me o Augusto Meyer que você está de acordo com a retirada dos sócios da A.B.D.E., uma vez que a nossa associação se tornou mais política do que profissional. Assim sendo, tenho a liberdade de remeter-lhe a inclusa lista de assinaturas, pedindo-lhe colocar aí a sua, desde que isto não o constranja. (ANDRADE, 1949b).

No princípio de maio, o jornal $A$ manhã anunciou a saída de 430 sócios da entidade, o que liquidava a associação. (A ABDE..., 1949, p. 1). Foi uma vitória pessoal de Drummond diante dos comunistas, num episódio que colocou fim à ideia de associação dos escritores em torno de uma causa comum. Após a ABDE, nenhuma outra entidade de profissionais da escrita conseguiu expressividade no país.

A propósito da personalidade de Drummond e da postura que adotou diante dos antigos companheiros de ideologia após o episódio, vale como aparte a carta que recebeu de Aydano Couto Ferraz, em face da morte de Cândido Portinari, antigo militante comunista e amigo de ambos. Ferraz, militante comunista, havia sido um dos diretores da Tribuna Popular com quem o poeta tivera diferenças quando trabalhou no jornal. Posteriormente, as diferenças se acentuaram, e os dois romperam relações durante 0 congresso da ABDE em Belo Horizonte. A morte de Portinari ocorreu em 1962, momento das paixões já terem se assentado, mas o poeta permanecia carregando a marca da desavença, segundo a carta de Aydano:

Em primeiro lugar esteja certo de que a nenhuma outra pessoa, a não ser você, eu escreveria em circunstâncias iguais a esta. Não mo permitiriam a minha consciência e o meu orgulho. Mas a você, que demonstrou ser meu amigo, dando-me um emprego condigno, amigo de um sujeito como eu, em cujo caráter a gratidão é traço relevante, há muito me sinto na obrigação de fazê-lo, embora as trágicas humilhações que você me tem imposto.

Essas humilhações chegaram ao auge, anteontem pela manhã, quando fui à Casa de Saúde São José visitar o corpo do nosso comum amigo Portinari, e você abaixou a vista para não falar comigo. Você, no seu desmedido orgulho, previu que aquele era o momento em que eu ia dirigirme a você. Como não tem razão alguma para manter-se nessa posição, baixou a vista. (FERRAZ, 1962).

A malfadada sina de Ferraz não terminaria aí. Na carta, ele descreve novo constrangimento, ocorrido no dia seguinte: 

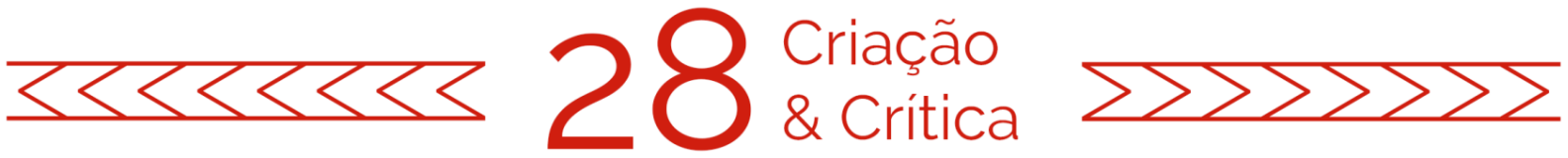

A noite estive velando o corpo de Candinho, com os amigos e a família, e só não fui ao enterro dele, na manhã seguinte, para não encontrar o amigo a quem sempre tanto quis, que é você, e sofrer nova humilhação. Para desgraça minha, entretanto, quando você voltava do enterro, em companhia de sua senhora, de paletó no braço, às 12,30, na rua Bulhões de Carvalho, ainda deparei com você. É demais. (FERRAZ, 1962).

Ferraz continua a carta falando da admiração que tinha pelo poeta, e justificando seus equívocos do passado: "Se durante o tempo da Tribuna Popular não dei a devida atenção ao amigo, ao qual eu mesmo fora portador do convite para figurar na direção do jornal, é que eu tomara sobre os ombros uma tarefa acima de minhas forças". Fala então do cargo que perdeu no serviço público por sua vinculação com o comunismo, do exílio na União Soviética e da desilusão com o partido, fazendo um apelo a Drummond: "Agora já passou tempo demais e é o momento de resolvermos essa situação. A injustiça já se prolongou demais e também já me incomoda demais. Você sabe perfeitamente que me faz sofrer com essa atitude" (FERRAZ, 1962). A carta não foi suficiente para convencer o poeta. Pela correspondência preservada, verifica-se que Drummond manteve-se em silêncio. Eles só retomariam o contato, ainda assim de forma distante, quinze anos depois.

De volta ao ano de 1949, após o caso da ABDE, Drummond passou a falar publicamente numa descrença do papel político do escritor. Em julho, foi convidado por Arnaldo Pedroso Horta para participar da diretoria de uma nova revista a ser criada em São Paulo, ao lado de Antonio Candido e Mário Pedrosa. ${ }^{3}$ Sua resposta foi taxativa: "Disposto a ajudar, mas não a fazer parte da direção, por não ser companheiro adequado, com a minha descrença atual no papel do escritor na vida pública". (ANDRADE, 1949c). Também neste momento, Drummond abandonou seu projeto de livro reunindo a poesia de caráter social produzida no Brasil. Sua ideia, concebida no auge da militância política, era reunir em um volume a poesia revolucionária produzida no Brasil desde Castro Alves até os contemporâneos. Em crônica publicada no mês de agosto no jornal $A$ manhã, ele sepultava o projeto no qual empenhara dois anos. Diz o texto:

Doce é projetar, rude é cumprir. Por isso não se publicou ainda a antologia brasileira de poesia social, que o autor destas linhas levou dois anos a compor, caceteando feio e forte amigos daqui e de São Paulo. Lidas algumas centenas de volumes, sobraram uns tantos poemas, que pareceram bons ou passáveis, e foram organizados segundo o plano da obra. Restava juntar-Ihes notas explicativas. Não juntei. Os originais formam um bolo bastante incômodo na gaveta, e cada vez que olho para esse bolo me pergunto: valerá a pena?

Devo dizer honestamente que nem a poesia de caráter social me parece a melhor de nossa tradição, representada antes pelo lirismo romântico, nem esse gênero de poesia hoje me interessa muito. Andanças da sensibilidade, aos sacolejos entre as experiências do espírito e as do

\footnotetext{
${ }^{3} \mathrm{~A}$ pesquisa não conseguiu identificar o título da revista.
} 

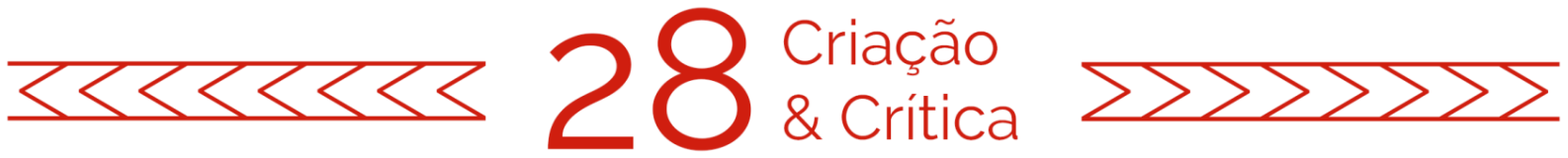

homem cívico, sois talvez causa próxima desse desinteresse. Mas, passemos. (ANDRADE, 1949d).

Após o rompimento com os comunistas, Drummond mostrava-se amplamente desiludido com este gênero de poesia que chegou a praticar em seus livros dos anos 1930 e 1940, sobretudo em A Rosa do Povo. Em 1954, numa carta ao amigo Cyro dos Anjos, o poeta escreveu que estava preparando para a editora José Olympio uma edição de suas poesias completas, "por sinal que com certo nojo da fase política de minha versalhada, que pensei até em suprimir, mas, refletindo melhor, achei acertado manter, publicando talvez uma nota explicativa". (ANDRADE; ANJOS, 2012, p. 192). Isso não significava, no entanto, uma descrença no papel do escritor enquanto agente da vida pública, como o poeta quis sugerir ao negar sua participação na revista paulistana. Se por um lado sua poesia deixava de incorporar os temas sociais, a participação cívica na vida política nacional continuava vigorosa, agora com a postura anticomunista. No ano de 1950, Drummond apoiou Cristiano Machado, candidato escolhido por Dutra para ser seu sucessor. Numa experiência única em sua trajetória, o poeta elaborou os discursos políticos que animaram a campanha.

Cristiano Machado foi lançado candidato à presidência pelo PSD, e concorreu com Eduardo Gomes, da UDN, e Getúlio Vargas, do PTB. Sua candidatura foi uma estratégia de Dutra, que pinçara um político de Minas Gerais, pouco conhecido no cenário nacional, para dar continuidade a seu governo, numa tentativa de combater Vargas, que aparecia como favorito nas urnas. Neste pleito, os comunistas ficaram sem um candidato possível, e Luís Carlos Prestes lançou uma carta aberta aos correligionários para que votassem em branco na escolha do presidente. Para ele, a única saída para os trabalhadores naquele momento, 1950, seria a revolução. Cristiano Machado acabou em terceiro lugar no pleito, diante da vitória esmagadora de Vargas, que contou até com votos de comunistas desobedientes a Prestes. Sua candidatura foi esvaziada mesmo dentro de seu partido, num processo que ganhou apelido de "cristianização", e até hoje é jargão político no país.

Drummond tinha relações com Machado desde sua juventude em Minas, e, além de redigir os discursos, tentou obter para ele os votos da família. Em carta de setembro de 1950 ao irmão Flaviano, escreveu: "Se isto não contrariar convicção profunda de sua parte, gostaria que, na próxima eleição, você ajudasse um pouco o Cristiano e o Capanema, votando neles e obtendo também para ambos os votos da família". Gustavo Capanema, antigo chefe do poeta no Ministério da Educação e Saúde, era então candidato a deputado federal. "São dois velhos amigos meus, muito dignos e capazes, e sempre dispensaram toda a consideração ao nosso pessoal", continuava a carta. "Para Minas, por certo que é da maior importância colocar na Presidência uma pessoa que, afinal, cuide de uma terra tão abandonada nos últimos anos" (ANDRADE, 1950a).

Seu empenho na campanha fica expresso em outra carta, escrita à cunhada Ita por ocasião da apuração dos votos, em outubro daquele ano. Dizia ter sido inteiramente absorvido pela campanha eleitoral no decorrer das últimas semanas. "Infelizmente, esse 

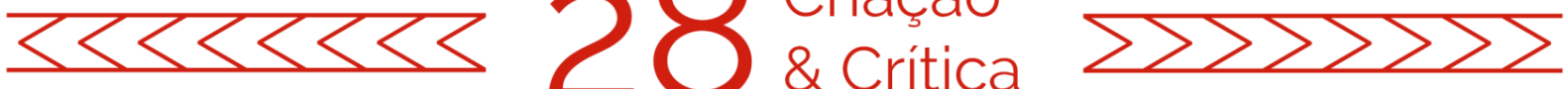

esforço foi inútil, à vista dos primeiros resultados que o rádio vem divulgando e que fazem prever a decisão do pleito", observou. "Se as preferências do povo se inclinam para quem sabe iludi-lo, nada nos resta fazer, senão aguardar o resultado". (ANDRADE, 1950b).

No mesmo momento em que atuava na campanha presidencial, Drummond começou a publicar na imprensa os poemas que comporiam seus dois livros seguintes, Claro enigma e Viola de bolso. O primeiro livro traz um poeta angustiado, reflexivo diante da condição humana. Se no plano político sua opção foi partir para um caminho anticomunista, no poético ele preferiu evadir-se da batalha ideológica, produzindo versos desencantados, que tratam do amor, da velhice e da dissolução, sem qualquer traço da esperança e do espírito de comunhão que animou $A$ rosa do povo.

Em suas escolhas pelo título do livro, fica claro que Drummond pretendia naquele momento fazer uma poesia mais interior do que coletiva, que negava e questionava ao invés de afirmar, e recusava a realidade imediata em nome de uma humanidade mais profunda. Em agosto de 1951, o poeta escreveu a Abgar Renault a propósito desta obra em que estava trabalhando:

O título que era Poemas Coloquiais, passou a Poemas Interiores, e agora oscila entre O real impossível, Profissão humana, Ofício de viver, Claro enigma, Rosto de madureza, Negação das cousas, Negação do tempo e... chega. Dê o seu palpite franco, para livrar-me de tanta perplexidade. (ANDRADE, 1951).

Viola de Bolso, publicado no ano seguinte, avança no campo da poesia de circunstância, onde as experiências pessoais e as relações literárias sobressaem, ficando em segundo plano a perspectiva de transformação política do mundo. Seus versos não são mais uma espada que atravessa o povo ou é por ela atravessada, como em "Consideração do poema", mas retrato de uma realidade íntima. O poema "Apelo aos meus dessemelhantes em favor da paz", no qual o autor pede aos jovens escritores que não Ihe tragam originais para ler, parece uma negativa direta ao poeta que em 1940 conclamava o mundo a andar de mãos dadas. Talvez por esse motivo, a maioria dos poemas de Viola de bolso foi publicada na imprensa sob pseudônimo.

$\mathrm{Na}$ época, Drummond era chamado de traidor pelos jornais comunistas, e a publicação de poemas de sua lavra com motivos tão alheios aos que defendeu no passado poderia dar combustível aos ataques. Assim, entre os poemas de Viola de bolso, os seguintes apareceram nos jornais sob pseudônimo: "A dança e a alma" (atribuído a Aluizio Goulart), "Maio no Leblon" (Aloísio Goulart), "Homem tirando a roupa" (Djalma Nobre), "Divina pastora" (Alcino Braga), "Luar em qualquer cidade" (Aloísio Goulart), "Assombração" (J. Dionísio), "O amor em viagem" (Rui Santana), "Tempo e olfato" (Mário Teófilo) e "A cidade sem rio" (Aldo Mendes). Mesmo um poema em homenagem ao espanhol Federico García Lorca, ícone dos republicanos comunistas, "Invocação com ternura", apareceu na imprensa sob o pseudônimo de Aluísio Goulart. ${ }^{4}$

\footnotetext{
${ }^{4}$ Estes poemas assinados por pseudônimo foram publicados no Correio da Manha, entre os anos de 1950 e 1951. Drummond recolheu os recortes de jornal em uma pasta, que indica a publicação de cada um deles,
} 

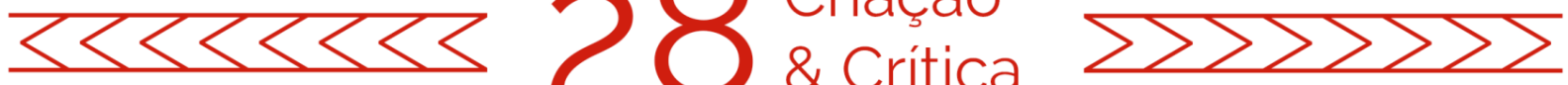

Também foram assinados nos jornais pelo pseudônimo de Leandro Sabóia os seguintes poemas que entraram em Claro enigma: "Estampas de Vila Rica", "Opaco", "O relógio do rosário", "Campo de flores" e "Rapto". ${ }^{5}$ A nossa pesquisa não conseguiu identificar os critérios usados para a utilização de pseudônimos, já que no mesmo período foram publicados na imprensa poemas de Claro enigma com assinatura de Drummond.

$O$ uso de nomes falsos pode ter sido uma tentativa de evitar julgamentos prévios, poupando os poemas de serem avaliados sob a influência das paixões que seu nome despertaria. A mudança de tom em sua escrita, no entanto, não seria definitiva, nem iria pacificar todas as suas questões internas relativas à poesia social. Em 1954, mesmo ano em que afirmou numa carta a Cyro dos Anjos sentir "nojo" de seus versos mais engajados, o poeta ainda expunha sentimentos não resolvidos sobre a função social da literatura. Em entrevista a Lya Cavalcanti, declarou:

Tudo o que já se escreveu e discutiu sobre arte social e arte pura não deu para dirimir a questão. $O$ tesouro estético do mundo alegra, alimenta, consola os privilegiados, que têm acesso aos seus primores, mas as grandes massas humanas parecem condenadas para sempre a não participar do festival. Eu pergunto se não há um egoísmo fundamental no criador literário, no artista, que se distrai com as formas da beleza, com o jogo sutil do espírito, enquanto a realidade em volta é apenas o esforço pela sobrevivência, sem qualquer horizonte, qualquer Gioconda no museu. (ANDRADE, 2008, p. 92).

Embora vivesse esse tipo de dilema interno, o poeta nunca mais retornou ao engajamento afirmativo de $A$ rosa do povo. Nos poemas e crônicas que escreveu até 0 final da vida, Drummond alternou o intimismo e a preocupação estética com um certo humanismo que pode ser considerado um tipo de resquício do poeta comunista. Mas o alheamento às questões políticas que passou a adotar lhe rendeu também fama de alienado e conservador. Em 1965, logo após o golpe militar no país, o poeta foi advertido por um leitor do Correio da manhã que criticava a temática de suas crônicas: "No mesmo dia em que o seu jornal analisa a grave ameaça que representa para a vida brasileira o período da ditadura, vossa senhoria se compraz em falar sobre palmeiras". (MELO, 1965). A justiça deste tipo de crítica caberá a um estudo futuro avaliar.

nas seguintes datas, respectivamente: 12 de março de 1950, 7 de maio de 1950, 6 de agosto de 1950, 18 de março de 1951, 22 de abril de 1951, 29 de abril de 1951, 24 de junho de 1951, 29 de julho de 1951, data ignorada de 1951, 10 de setembro de 1950. Acervo Carlos Drummond de Andrade, recortes de jornal. Fundação Casa de Rui Barbosa, Rio de Janeiro.

5 Todos estes publicados no Diário Carioca, no ano de 1951. Também foram recolhidos por Drummond em uma pasta de recortes, que indica a sua publicação nas seguintes datas, respectivamente: 16 de setembro de 1951, 25 de novembro de 1951, 22 de dezembro de 1951, janeiro de 1951, 1 de abril de 51. Acervo Carlos Drummond de Andrade, recortes de jornal. Fundação Casa de Rui Barbosa, Rio de Janeiro. 

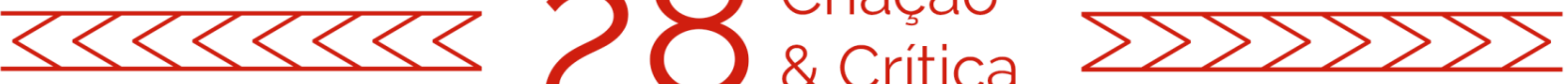

\section{Referências}

A ABDE SEM ESCRITORES, autor desconhecido. A Manhã, Suplemento "Letras e Artes", Rio de Janeiro, 8 de maio 1949.

AGREDIDO PELOS COMUNISTAS O ESCRITOR CARLOS DRUMMOND DE ANDRADE, autor desconhecido. Diário da Noite, Rio de Janeiro, 8 de abril de 1949.

ANDRADE, Carlos Drummond. Nova Reunião, 23 livros de poesia. Rio de Janeiro: Editora Record, 2009

novembro de 1947.

"Nota sobre outro assunto". Correio da Manhã, Rio de Janeiro, 9 de

. [Correspondência]. Destinatário: Abgar Renault. Rio de Janeiro, 10 de abril de 1949a. Acervo Fundação Casa de Rui Barbosa, Rio de Janeiro.

[Correspondência]. Destinatário: Luís Cosme. Rio de Janeiro, 26 de abril de 1949b. Acervo Fundação Casa de Rui Barbosa, Rio de Janeiro.

. [Correspondência]. Destinatário: Arnaldo Pedroso Horta.

Rio de Janeiro. Manuscrito à margem da carta de 22 de julho de 1949c. Acervo Fundação Casa de Rui Barbosa, Rio de Janeiro.

"Poesia Social". A Manhã, Suplemento "Letras e Artes", Rio de Janeiro, 11 de setembro de 1949d.

[Correspondência]. Destinatário: Flaviano Andrade, Rio de Janeiro, de 13 de setembro de 1950a. Acervo Fundação Cultural Carlos Drummond de Andrade. Itabira, MG.

[Correspondência]. Destinatário: Ita Andrade, Rio de Janeiro, de 5 de outubro de 1950b. Acervo Fundação Cultural Carlos Drummond de Andrade. Itabira, MG.

. [Correspondência]. Destinatário: Abgar Renault. Rio de Janeiro, 12 de agosto de 1951. Acervo Fundação Casa de Rui Barbosa, Rio de Janeiro.

Tempo vida poesia. Rio de Janeiro: Record, 2008.

ANDRADE, Carlos Drummond de; ANJOS, Cyro dos. Cyro \& Drummond. São Paulo: Editora Globo, 2012.

BOWRA, Maurice. Poesia y politica. 1900-1960. Buenos Aires: Losada,1969

CAMINHA, Edmilson (Org.). Drummond: a lição do poeta. Teresina: Corisco, 2002

CARTA A UM SÓCIO DA ABDE, autor desconhecido, recorte de jornal com título e data ignorados. Recortes ABDE, Acervo Carlos Drummond de Andrade, Fundação Casa de Rui Barbosa, Rio de Janeiro.

ENCERROU-SE O CONGRESSO DE ESCRITORES, autor desconhecido, recorte de jornal com título ignorado, 18 de novembro de 1947. Recortes ABDE, Acervo Carlos Drummond de Andrade, Fundação Casa de Rui Barbosa, Rio de Janeiro.

ESCREVEM A PIXE E FALAM A PONTAPÉS, autor desconhecido, O Mundo, Rio de Janeiro, 8 de abril de 1949. 

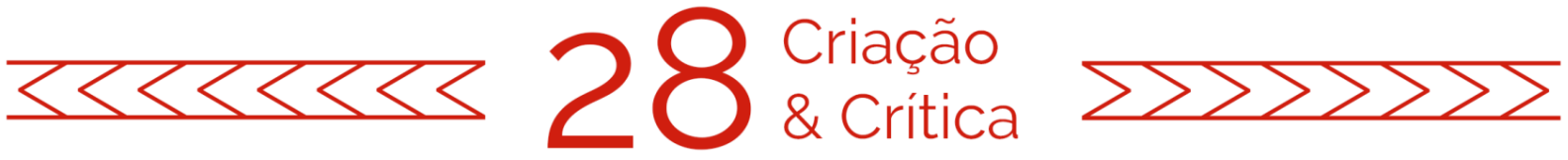

FERRAZ, Aydano Couto. [Correspondência]. Destinatário: Carlos Drummond de Andrade. Rio de janeiro, 6 de fevereiro de 1962. Acervo Fundação Casa de Rui Barbosa, Rio de Janeiro.

FIM DA ABDE, autor desconhecido, Folha do Norte, Belém, 8 de maio de 1949.

GOLPE DOS COMUNISTAS NA ASSOCIAÇÃO DE ESCRITORES, autor desconhecido.

Diário Carioca, Rio de Janeiro, 8 de abril de 1949.

JOBIM, Danton. "A jornada de ontem”, Diário Carioca, Rio de Janeiro, 27 de março de 1949

LACERDA, Carlos. "Uma eleição de escritores". Correio da Manhã, Rio de Janeiro, 20 de março de 1949.

LINS, Álvaro. "O caso da ABDE", Correio da Manhã, Rio de Janeiro, 24 de março de 1949.

MELO, Sérgio. [Correspondência]. Destinatário: Carlos Drummond de Andrade. Rio de Janeiro, 5 de outubro de 1965. Acervo Fundação Casa de Rui Barbosa, Rio de Janeiro. OS QUIXOTES, autor desconhecido. Folha do Povo, Rio de Janeiro, 1 de abril de 1949. PELA VITÓRIA DA CHAPA DE UNIDADE DEMOCRÁTICA, autor desconhecido, recorte de jornal com título e data ignorados. Recortes ABDE, Acervo Carlos Drummond de Andrade, Fundação Casa de Rui Barbosa, Rio de Janeiro.

PROFISSIONAL E NÃO PARTIDÁRIA A ABDE, autor desconhecido, O Globo, Rio de Janeiro, 19 de março de 1949.

SQUEFF, Egydio. "Ponto Pacífico". Folha do Povo, Rio de Janeiro, 14 de março de 1949. UM GOLPE NOS COMUNISTAS DA ABDE, autor desconhecido, Diário Trabalhista, Rio de Janeiro, 14 de novembro de 1947.

Recebido em: 22/07/2020

Aceito em: 08/09/2020

Referência eletrônica: BORTOLOTI, Marcelo. Drummond e a Associação Brasileira de Escritores: desencontros e ruptura. Criação \& Crítica, n. 28, p., dez. 2020. Disponível em: <http://revistas.usp.br/criacaoecritica>. Acesso em: dd mmm. aaaa. 